\title{
URBAN SPRAWL: AN ANALYSIS OF URBAN EXPANSION IN BORI AREA- A GEOGRAPHIC INFORMATION SYSTEM APPROACH
}

\author{
Agbora, Barizaa \\ Department of Urban and Regional Planning, \\ Rivers State University, Port-Harcourt, \\ Rivers State, Nigeria
}

Abstract: As the world move towards the 21st century, there have been renewed efforts to deliberately change the socio-economic status of the people in the positive direction through coordinated planning approach. Rapid urbanization often creates a situation where peripheral lands are subjected to intense pressure a phenomenon that precipitates rapid land-use dynamics, as rural areas are made to be part of the city leading to urban sprawl. This study examined urban expansion of Bori with a view to $x$-raying if the land use changes in the area conform to the previsions of the 1972 Master plan. Adopting a longitudinal survey research design, the Bori Master plan 1972 was retrieved from the planning authority in the area while the 2003 and 2018 map were sourced from the Google Imagery and analyzed using ArcGIS version 10. The result of the analysis shows that the present growth pattern of Bori is at variance with the provision of its 1972 prepared plan. Residential land use increased from 1,302.7hactares in 1972 to $5,302.7$ hectares in 2003, and 7,507.3 hectares in 2018 respectively. Commercial land use also grew at $\mathbf{1 4 4 . 8}$ hectares' in 1972 to $\mathbf{1 4 0 . 4 h a c t a r e s}$ in 2003 and to 1,117.3 hectares in 2018. Sharp decline in the land for forest and agriculture were also observed. Bori area had a total land devoted for forest covering $65.4 \%$ about 10,159.6 hectares in 1972, this figure dropped to 1137.2 hectares a mere $7.3 \%$ in 2018. The same scenario was observed for institutional land-use which stood at 822.6 hectares $(5.3 \%)$ in 1972 but increased to 2537.1hactares (16.3\%), and 3782.1hactares $(\mathbf{2 4 . 3 \%})$ in 2003 and 2018 respectively. The study among other things, recommends for the formulation of policies by the Government by way

\author{
Weje, Ikezam Innocent \\ Department of Urban and Regional Planning \\ Rivers State University, Port-Harcourt, \\ Rivers State, Nigeria
}

of reviewing the existing Master plan and securing its effective and full implementation. To achieve this will require strengthening of extant planning legislations in the area and full involvement of the citizens of Bori area in the master plan implementation.

Key word: Master plan; balanced growth; Land-use planning; urban sprawl, Master plan

\section{INTRODUCTION}

As the world move towards the 21st century, there have been renewed efforts to deliberately change the socio-economic status of the people in the positive direction through co-ordinate planning approach. These approaches or strategies according to Turner and Hulm (1997: 134)[1] usually involve the creation and formulation of policies to achieve effective development outcomes for citizens through the adoption of development plan approach. Akin to the above, is the desired need to guide against haphazard growth of cities in space. The argument is that the efficiency and livelihood of urban settlements largely depends upon how well they are planned, how economically they are developed and how efficiently they are managed.

With lopsidedness in the growth of urban centers in developing economies, urban planning has assumed major importance as a veritable profession for social engineering for integrating large regions with their hinterlands such that development proceeds in a balanced form in space. It is for this reason that The New Urban Agenda was adopted at the United Nations Conference on Housing and Sustainable Development (Habitat III) in Quito, 
International Journal of Engineering Applied Sciences and Technology, 2019

Vol. 4, Issue 3, ISSN No. 2455-2143, Pages 507-514

Published Online July 2019 in IJEAST (http://www.ijeast.com)

Ecuador in October 2016. The Agenda is a shared vision in which the international community reconsiders the urban systems and physical forms of urban spaces to achieve equal rights and access to the benefits and opportunities that cities can offer (Owei, 2017)[2]. The New Urban Agenda lays out standards and principles for the planning, construction, development, management and improvement of urban areas based on the five pillars of implementation i.e. national urban policies, urban legislation and regulation, urban planning and design, local economy and municipal finance and local implementation. (United Nations, 2017).[3]

The creation of Rivers State in 1967 brought with it, radical changes in the socioeconomic and political spheres of the area. This creation led to rapid investment in the provision of social infrastructure and amenities in certain areas (Port Harcourt). Unfortunately the provision of these amenities accentuated rural-urban migration leading to rapid population growth of Port Harcourt with attendant negative consequences one of which is encroachment of settlement along water fronts (Weje and Dapa, 2018)[4] and rapid extension of growth to adjoining settlements including Bori town.

In response to rapid urban growth and as a deliberate policy to encourage the growth of other towns, the first military administration of the state under then, Commodore Alfred Diete-Spiff launched a major planning initiative, first to designate the headquarters of the administrative divisions of the state as urban centers and, secondly, to prepare master plans to guide their development (Owei, 2017)[2]. Bori Town was one of these administrative centers so created and whose master plan was drawn at this epoch with a plan period of 1972-2002

How well has the implementation of Bori master plan proceeded when judged against set objectives is a matter of controversy. This paper is an attempt to x-ray the Bori Master Plan of 1972 and the accompanying land use changes vis-a-vis the provisions in the prepared Master plan. This is against the backdrop that physical observation of the land use development of Bori seem to have differed significantly from the various projections of the prepared plan with very negative implications on the physical environment and livelihood of Bori residents.

\section{STUDY AREA}

Bori is situated in Khana Local Government Area, Ogoni, Rivers State, Nigeria. Its geographical coordinates are within latitude $4.67^{0}$ North, longitude $7.36^{0}$ East. Bori is the traditional headquarters of Ogoni people. Bori urban area comprises of adjoining communities including Bori town, Bua Yeghe, Zaakpon, Wiiyakara, Betem, Kor, Kpong and Bo-ue. The climate of Bori is tropical and rainy, as characteristic of the Niger Delta region. The average rainfall is 107.6 inches, the dry season last from December to March, Rain increases in March and April, reaching its peak in July after which there is generally a short dry period in August. Bori region has witnessed very rapid urban growth occasioned by the changes in the socio-economic live of the area. Its close proximity to the State capital (Port Harcourt) coupled with the presence of Oil and gas firms including the Ken Saro-Wiwa Polytechnic (also known as River State Polytechnic) are all some of the factors accounting for its fast growth. This rapid growth in physical expansion and population wise has however impacted on the land use characterization of the area.

\section{METHODS AND MATERIALS}

This study adopted the longitudinal survey research design since the research do not intend to manipulate the variables under investigation (Cook and Campbell, 1979)[5]but seeks to examine on-thespot land use characterization of Bori vis-à-vis its prepared master plan of 1972. Both primary and secondary sources of data were used. Primary data were collected via the use of personal field observation and ground truthing exercise carried out to complement the data gotten from the secondary source. To examine the land use characteristics of the study area, the 1972 Bori master plan was acquired from the Rivers State Ministry of Urban development Port Harcourt. Again, the satellite imageries of Bori for 2003 and 2018 were Google Imagery at 45 meters resolution.

The satellite imageries of the study area were entered into an ArcGIS and digitized. Further analysis on the law use dynamics were achieved through ensuring of different query commands. Results from the analysis were subjected into simple percentages. Data presentation was done through the use of maps and tables for easy understanding. 
International Journal of Engineering Applied Sciences and Technology, 2019

Vol. 4, Issue 3, ISSN No. 2455-2143, Pages 507-514

Published Online July 2019 in IJEAST (http://www.ijeast.com)

\section{THEORETICAL FRAMEWORK AND RELATED LITERATURE}

Town Planning as an art has gone through the influences of so many philosophical approaches in history. From the city beautification era of the Baroque period, to the time of the reformers of the 'utopian' thinkers, planning have been guided by different ideological stance and schools of thought. With the setting in of industrialization and its associated challenges on urban form, cities came to be perceived as a system of building and structures that could be arranged and re-arranged through planning to produce an ideal city through the incorporation of Master Plan principles (Agbola and Oladoja, 2004).[6] The assumption that people's lives are shaped by their physical surrounding, made the preparation of master plan popular at this era.

With the passage of time however, the master plan concept came under serious attack, one of which is its inability to take into account the influences of social, political and economic structures and processes in determining urban form. Specifically, it has been said that master plan usually tries to contain dynamic phenomena in a static environment by setting limit boundaries and are insensitive to changes taking place in city growth Agbola and Oladoja, 2004).[6]

Over time planning came to be seen as both a method and a process of decision-making hence the emergence of the rational comprehensive planning model. For this rational model, planning is an object value-free enterprise. Proponents of rational comprehensive planning thought that the more comprehensive the analyses of the problem were, the better the plan would be. The planner-analyst regarded as the neutral observer of the problem would formulate and undertake analyses and provide valid knowledge of problems out there and that through profound analyses, one may predict the long term master plan with great accuracy to steer development.

Writing on this, Faludi (1986) [7] argues that planning as a decision-making process should aim at solving some of the diverse problems which planners face. For him, planning should be rational by evaluating comprehensively all possible action in the light of their consequences; and ensuring that these considerations include alternative goals and that planning should also respond flexibly to new situations. The rational comprehensive model has again been criticized on the grounds that humans have limited intellectual capacities and no one problem can tightly or rationally be formulated. The rejection of this model gave way for the disjointed incrementalism approach as a normative model. The focus of the model is that the planners have facts and values which are difficult to separate in any analysis. For the incrementalists, since human values change with time and experience, our conception of the circumstances and choices will have to change from moment to moment becoming problem-directed rather than a goal- directed approach (Agbola \& Oladaja, 2004).[6]

The incrementalism model does not attempt a comprehensive objective and rational approach to dealing with planning problems; instead, it deals with such problems in a disjointed manner with only marginal departure from previous action or decision. Since the approach can best be regarded as partial, it is seen as a trial and error model. This characteristic makes the model to be tagged "the Science which muddles through planning problems" (Omuta and Onokerhoraye,1994) [8] and seeks quick fix answers to issues that cannot wait for a comprehensive analysis before action can be taken.

The mixed scanning model came as a remedy to the challenges of rational and disjointed incrementalism. The objective of mixed seaming is to make a distinction between a higher - order fundamental policy making process which sets basic directions and an incremental process which prepares for fundamental decision and revise them after they have been made. Planning has also moved in favour of the systems approach. The systematic planning approach aims at adjusting continuously to changes, to changing conditions and to circumstances. This approach sees the human environment as a system with parts of component on one hand and connections of interactions on the other. It is an inherent behavioural and totally flexible approach to planning compared with the master planning method.

With the passage of time came the normative planning models whose emphasis is on how democratic principles can be applied to enhance planning outcome. The communicative planning models were originally developed by Habermas and further developed by Forester (1989) [9]. For Forester access to information and understanding the decision making process is crucial in planning and planners need to include communication practices to their technical work in order to encourage community participation. Forester (op cit) was concerned with 
political dimension of planners work and his major work evolved around power use in decision making processes. He also pointed out that planners, in a way they use the information in planning process, can empower

Forester (1989) [9] acknowledged that planners have in many situations little influence upon implementation of their plans but he stressed that they have impact on creation of conditions under which citizens are able to participate, act and organize their lives. They can do this in many ways through document creation and selection of participants, but the major power in the planning process that they have is their control over information. Knowledge and understanding in communicative planning concept is developed through mutual learning and through communication about challenges, dilemmas and possibilities (Forester op cit) [9]

Some many scholars have written copiously on the subject area. George (2002) [10] in his study of Olaleye-Ipronri urban development scheme of 1985 observed that prior to the scheme, citizen inputs into urban renewal and indeed any physical planning projects were noticeably absent. As such it was not surprising therefore the planners who prepared the master plan for Lagos metropolis noted that town planning in Nigeria has been criticized for ineffectiveness and this has been traced to lack of citizens' participation. Danmole (2004)[11] in his study of sustainability and city development: a critique of the implementation of the Abuja master plan showed that Abuja master plan besides including the major elements of the regional development plan for the territory, the plan intended to regulate land use, transportation systems, infrastructures, housing and other services in a manner that recognized their interrelationships and spatial requirement which are paramount in any physical planning exercise of its magnitude.

The review of literature made above all point to fact that master plan constitute effective tools for urban growth management. The Bori master plan was drawn in the year 1972 to guide spatial development of Bori and adjoining settlements. How well the master plan has preceded in terms its level of implementation has not been critically assessed. This constitutes a gap in literature which the present study intends to fill.

\section{RESULTS AND DISCUSSIONS}

Table 1 depicts the land use budget of Bori area for 1972, 2003 and 2018 respectively. From the table, Bori area had a planning area covering a total area of 15539.6 hactares in 1972. Out of this number, land devoted to residential land use was $1,302.7$ ha.( $8.4 \%$ ), commercial land use about 144.8 ha $(0.9 \%)$, agricultural/green land use was $2,923.3$ ha $(18.8 \%)$, forest occupied 10,159.6 ha (65.4\%), institutional land use was 822.6 ha $(5.3 \%)$ while transportation land use was $186.6(1.2 \%)$ respectively.

Table 1: land-use Budget of Bori, 1972-2018

\begin{tabular}{|c|c|c|c|c|c|c|}
\hline S/No. & Land Use & $1972(\mathrm{Ha})^{*}$ & $2003(\mathrm{Ha})^{* *}$ & $\begin{array}{l}\% \Delta \\
2003\end{array}$ & $\begin{array}{l}2018 \\
(\mathrm{Ha})^{* *}\end{array}$ & $\begin{array}{l}\% \Delta \\
2018\end{array}$ \\
\hline 1 & Residential & $\begin{array}{l}1,302.7 \\
(8.4 \%)\end{array}$ & $\begin{array}{l}5,302.7 \\
(34.1 \%) \\
\end{array}$ & 307.05 & $\begin{array}{l}7,507.8 \\
(48.3 \%) \\
\end{array}$ & 41.52 \\
\hline 2 & Commercial & $\begin{array}{l}144.8 \\
(0.9 \%)\end{array}$ & $\begin{array}{l}440.4 \\
(2.8 \%\end{array}$ & 204.14 & $\begin{array}{l}1,117.3 \\
(7.2 \%)\end{array}$ & 153.70 \\
\hline 3 & Agricultural/green & $\begin{array}{l}2,923.3 \\
(18.8 \%)\end{array}$ & $\begin{array}{l}1,998.4 \\
(12.9 \%)\end{array}$ & 31.64 & $\begin{array}{l}1,535.3 \\
(9.9 \%)\end{array}$ & -23.17 \\
\hline 5 & Forest & $\begin{array}{l}10,159.6 \\
(65.4 \%)\end{array}$ & $\begin{array}{l}5,002.4 \\
(32.2 \%)\end{array}$ & -50.76 & $\begin{array}{l}1,137.2 \\
(7.3 \%)\end{array}$ & -77.27 \\
\hline 6 & Institutional & $\begin{array}{l}822.6 \\
(5.3 \%)\end{array}$ & $\begin{array}{l}2,537.1 \\
(16.3 \%)\end{array}$ & 208.42 & $\begin{array}{l}3,782.1 \\
(24.3 \%)\end{array}$ & 49.07 \\
\hline 7 & Transportation & $\begin{array}{l}186.6 \\
(1.2 \%)\end{array}$ & $\begin{array}{l}258.6 \\
(1.7 \%)\end{array}$ & 38,59 & $\begin{array}{l}459.9 \\
(3 \%)\end{array}$ & 77.84 \\
\hline & Total & 15539.6 & 15530.6 & & $15,539.6$ & \\
\hline
\end{tabular}

Source: *Bori Master Plan (1972)

** Authors Field work, (2018) 
International Journal of Engineering Applied Sciences and Technology, 2019

Vol. 4, Issue 3, ISSN No. 2455-2143, Pages 507-514

Published Online July 2019 in IJEAST (http://www.ijeast.com)

Note: Figures in parenthesis are percentage of total land-use; $\% \mathbf{\Delta}=$ percentage change

Land use characteristics of Bori area in 2003 and 2018 shows sharp deviation when compared with that of 1972. An interesting picture revealed in this analysis is that these deviations were noticed in all the land-uses. For example, residential land-use in 1972 was $1,302.7$ hectares, but rose to $5,302.7$ hectares and 7,507.8 hectares in 2003 and 2018 respectively. The implication is that residential land use increased from $8.4 \%$ in 1972 to $48.3 \%$ in 2018 . For commercial land use the figure is 144.8 hectares in 1972, 440.0 hectares, and 1117.3 hectares in 2003 and 2018 respectively.

The result also indicates sharp decline in the land for forest and agricultural uses within the year under review. In 1972 when the master plan was prepared, Bori area had a total land devoted for forest covering $65.4 \%$ about 10,159.6 hectares, this figure dropped to 1137.2 hectares a mere $7.3 \%$ in 2018 . The same scenario was observed for institutional land-use which stood at 822.6 hectares $(5.3 \%)$ in 1972 and increased to 2537.1hactares (16.3\%), and 3782.1hactares (24.3\%) in 2003 and 2018 respectively.
Land use changes were also notices in agricultural land-use. A total of 2,923.3 hectares of land were devoted for Agricultural/green area in 1972. By2003 agricultural land decreased to $1,998.4$ hectares and with a further decrease to $1,535.3$ hectares in 2018. For transportation land use it was 186.6 hectares in 1972, 258.6 hectares in 2003 and 459.9 hectares in 2018.

A fascinating aspect of the study is the facts that while some land-uses had sharp reduction others increased in their size. Specifically saying, residential, commercial and institutional land-uses witnessed substantial increase in their land coverage, others such as forest area, agricultural land-uses recorded sharp decline. The gain and loses between and among various land-uses may be ascribed to the changes in the socio-economic and political life of Bori area. These changes coupled with rapid urbanization and pressure on land resources often results to the conversion of agricultural and forest land to residential, institutional and commercial uses. Figures 2, 3 and 4 depict the land use budget of Bori for 1972,2003 and 2018 respectively.

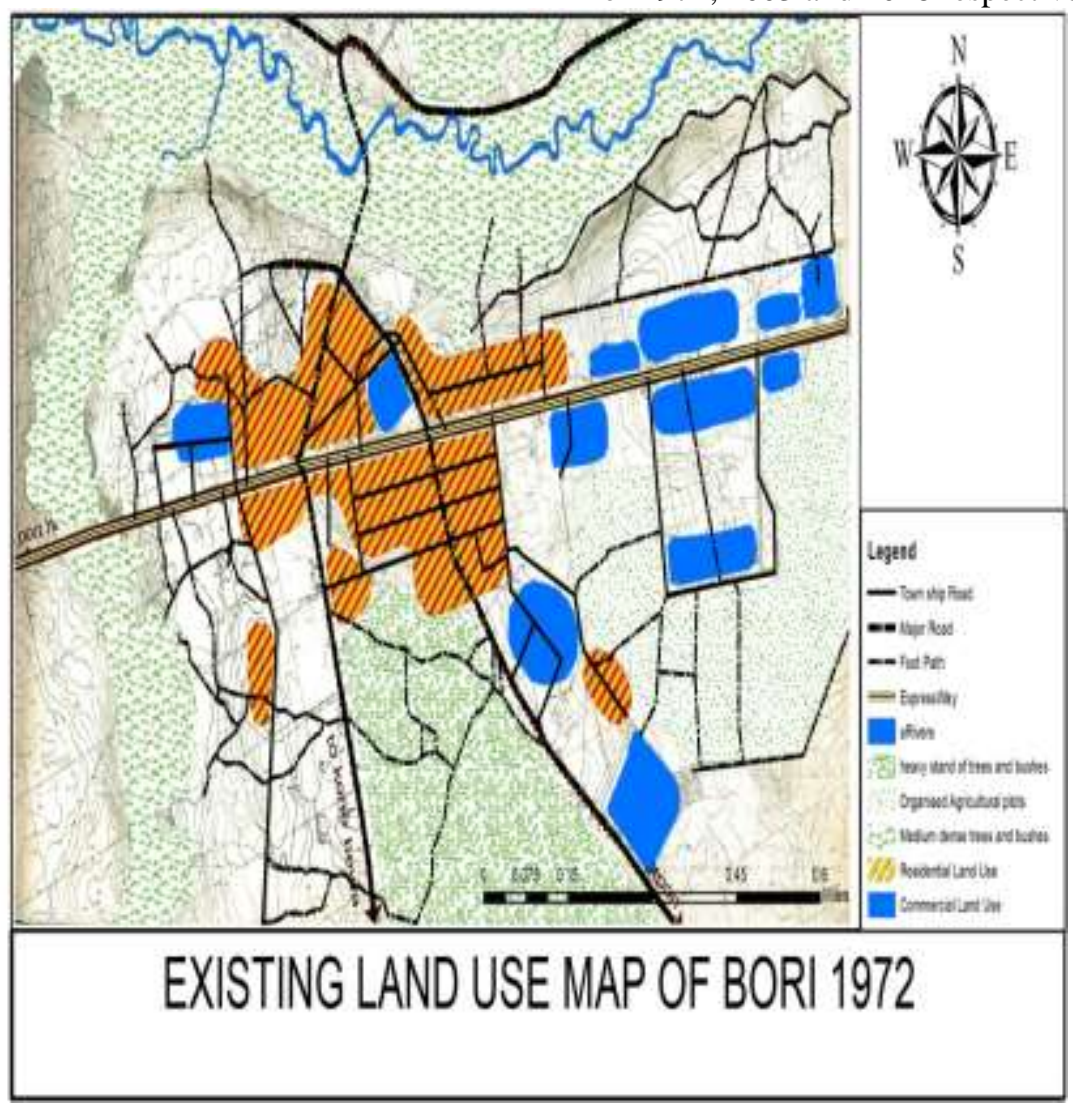

Figure 2: Land Use Budget of Bori in 1972 
International Journal of Engineering Applied Sciences and Technology, 2019

Vol. 4, Issue 3, ISSN No. 2455-2143, Pages 507-514

Published Online July 2019 in IJEAST (http://www.ijeast.com)

Source: Bori Master Plan (1972)

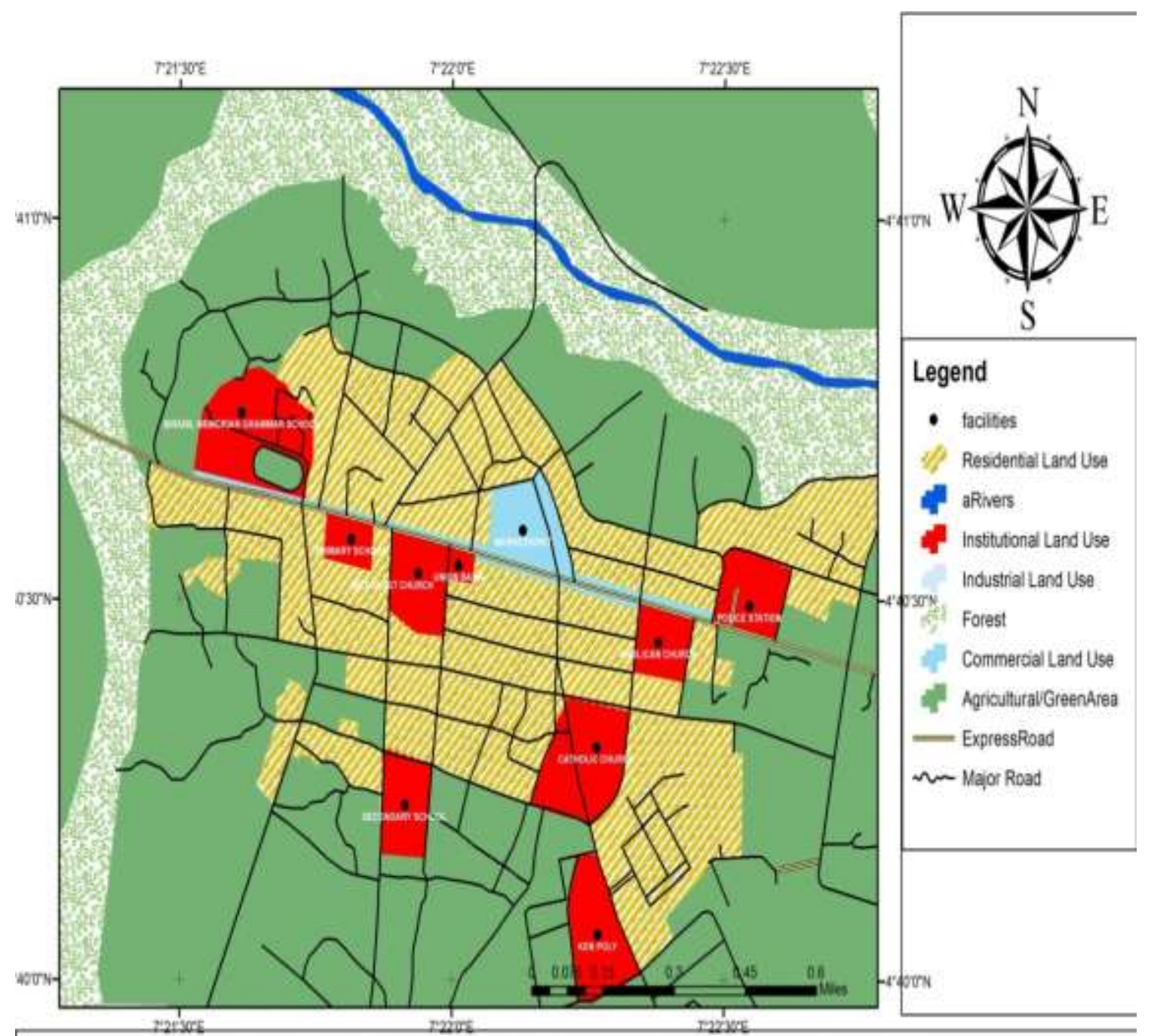

\section{EXISTING LAND USE MAP OF BORI 2003}

Figure 3: Land Use Budget of Bori in 2003

Source: Adapted from Google Imagery (2003) 


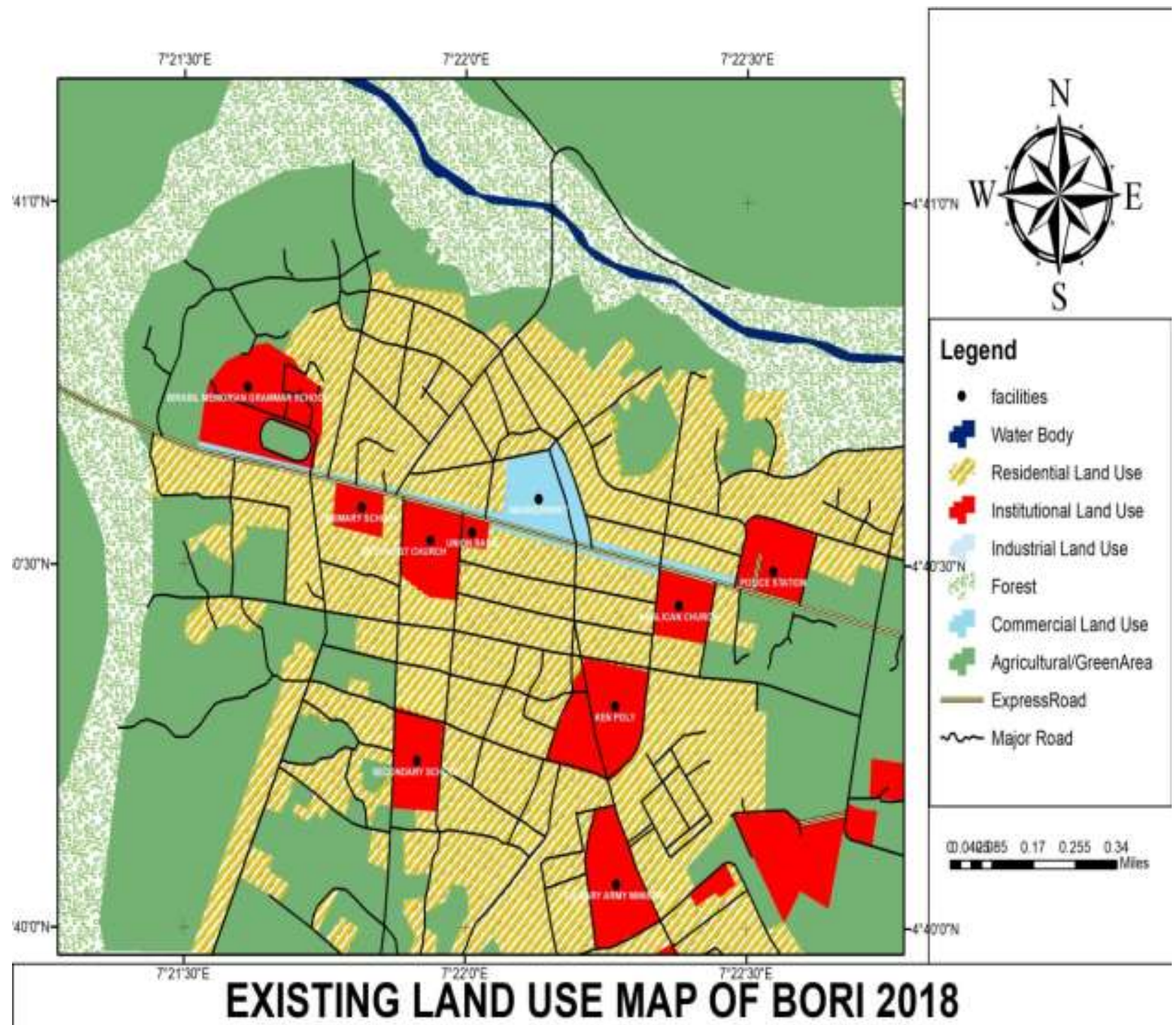

Figure 4: Land-Use Budget of Bori in 2018

Source: Adapted from Google Imagery (2018)

\section{CONCLUSION AND RECOMMENDATION}

Rapid urbanization often creates a situation where peripheral lands are subjected to intense pressure. This phenomenon also accounts for rapid land-use dynamics, as rural areas are made to be part of the city leading to urban sprawl. Harishkumar and Chinnappa (2017)[12] describes this process as gradual but steady change of rural landscape to urban-scape, where in land use systems like agricultural, fallow and forest lands are turned into built-up and non-agricultural uses. Following the changes in the socio-economic life of Bori town, there are noticeable changes in the land use pattern of the area as various land-uses compete for land space. This dynamism that goes with the struggle for land precipitates a situation where there is rapid reduction in agricultural land space and land devoted as forest reserve in contrast to the provision of the development plan of the area. 
International Journal of Engineering Applied Sciences and Technology, 2019

Vol. 4, Issue 3, ISSN No. 2455-2143, Pages 507-514

Published Online July 2019 in IJEAST (http://www.ijeast.com)

The implication of rapid conversion of agricultural lands to other uses may negatively affect food supply and worsen the poverty situation in the area since most residents of the area have agriculture as a major source of livelihood. In view of the above, urgent but strong measures aimed at reducing the pressure of development on the residence of Bori and environs are required. Such measure among other things includes the adoption of land use planning approach to encourage the growth of other towns as counter-development points. There is therefore the need for a review of the Bori Master plan and the strict monitoring of planning regulations in the area.

\section{REFERENCE}

1. Turner, M. and Hulme, D. (1997) Governance, Administration \& development: Making the State Work, Palgrave New York

2. Owei, O.B. (2017). Global urban Transformation and the challenges of building The $21^{\text {st }}$ century Nigeria city An inaugural lecture Series 51, Rivers State University, Port Harcourt, January, 2017

3. United Nations (UN). (2017). New Urban Agenda: Quito Declaration on Sustainable Cities and Human Settlements for All. United Nations (UN), Department of Economic and Social Affairs, Population Division (2016). The World's Cities in 2016 - Data Booklet (STIESAJSER.A1393

4. Weje, I.I.,and Dapa, I.N. (2018). Spatio-Temporal Analysis of Wetland Conversion in Port-Harcourt Municipality, Rivers State. International Journal of Humanities an Social Studies. Vol.6. No.8., pp253261

5. Cook TD, Campbell DT. (1979) Quasi experimentation: design and analysis issues for field settings. Chicago: Rand McNally Publishing Company.

6. Agbola, T. and Oladoja, A. (2004). Philosophy and theory of Urban and Regional Planning. In: Agbolo, T. (ed) Readings in Urban and Regional Planning. Macmillan Nigeria Publisher Limited. Yaba, Lagos

7. Faludi, A., (1986).Critical Rationalism and Planning Methodology, Pion Limited, London: Brondesbary Park.

8. Onokerhoraye, A.G. Omata,E.D. and (1994).Regional Development Planning for Africa. The Benin Social Science Series for Africa. University of Benin, Benin City, Nigeria.

9. Forester, M. (1989). Planning in the face of Power. University of California press
10. George, C. K. (2002). Basic Principles and Methods of Urban and Regional Planning. Libro-gem Ltd, Lagos

11. Danmole, T. O. (2004). Sustainability andCity Development A critique of the implementation of the Abuja Master Plan.

Being a paper presented for publication by Environmental Conservation Research Team, FUT Akure. Department of Urban and Regional Planning, University of Lagos, Akoka-Yaba, Lagos, Nigeria.

12. Harishkumar, A.V., and Chinnappa, B.V. (2017). Impact of urbanization on Land-use pattern of Rural-Urban Gradient of Bengaluru North: An Economic Analysis. Economic Affairs, Vol.62, no.2, PP303-312 